\title{
Effects of zinc bearing palygorskite supplementation on the growth performance, hepatic mineral content, and antioxidant status of broilers at early age
}

\author{
Weili Yang', Yueping Chen', Yefei Cheng', Chao Wen', and Yanmin Zhou ${ }^{1, *}$
}

\begin{abstract}
* Corresponding Author: Yanmin Zhou Tel: +86-25-84396067, Fax: +86-25-84395314, E-mail: zhouym6308@163.com
\end{abstract}

'College of Animal Science and Technology, Nanjing Agricultural University, Nanjing 210095, China

Submitted Jul 20, 2016; Revised Oct 26, 2016; Accepted Dec 17, 2016
Objective: This study was conducted to investigate effects of zinc $(\mathrm{Zn})$ bearing palygorskite (ZnPal) supplementation on growth performance, hepatic mineral content, and antioxidant status of broilers at early age.

Methods: A total of 240 1-day-old Arbor Acres broiler chicks were allocated into 5 treatments with 6 replicates of 8 chicks each. Birds in 5 treatments were fed a basal diet supplemented with 0 (Control group; Analyzed Zn content: $81 \mathrm{mg} / \mathrm{kg}$ ), 20, 40, 60, and $80 \mathrm{mg} / \mathrm{kg} \mathrm{Zn}$ as ZnPal for 21 days, respectively. Blood, liver and intestinal mucosa were collected at 21 days of age. Results: Treatments did not affect growth performance of broilers during the 21-day study (p $>$ $0.05)$. The contents of hepatic $\mathrm{Zn}$ and magnesium $(\mathrm{Mg})$ were linearly increased $(\mathrm{p}<0.001)$ by $\mathrm{ZnPal}$ supplementation. $\mathrm{ZnPal}$ inclusion linearly $(\mathrm{p}=0.007)$ reduced malondialdehyde (MDA) concentration in serum. The activity of total superoxide dismutase (T-SOD) in liver increased linearly $(\mathrm{p}=0.001)$ with concentration of $\mathrm{ZnPal}$ in diet. $\mathrm{ZnPal}$ inclusion linearly $(\mathrm{p}=0.036)$ and quadratically $(\mathrm{p}=0.005)$ increased T-SOD activity, and linearly $(\mathrm{p}=0.012)$ increased copper/zinc superoxide dismutase (Cu/Zn SOD) activity in jejunal mucosa. The maximum responses of hepatic and jejunal antioxidant enzymes activities (T-SOD and $\mathrm{Cu} / \mathrm{Zn} \mathrm{SOD}$ ) were found when supplementing the basal diet with $60 \mathrm{mg} / \mathrm{kg} \mathrm{Zn}$ as ZnPal. Furthermore, ZnPal supplementation quadratically $(\mathrm{p}=0.001)$ increased $\mathrm{Cu} / \mathrm{Zn}$ SOD activity in ileal mucosa, and its maximum activity was observed in the diet supplemented with $20 \mathrm{mg} / \mathrm{kg} \mathrm{Zn}$ as ZnPal. Conclusion: $\mathrm{ZnPal}$ supplementation did not alter growth performance of broilers. Dietary $\mathrm{ZnPal}$ inclusion could increase concentrations of hepatic trace minerals $(\mathrm{Zn}$ and $\mathrm{Mg}$ ) and inhibit lipid peroxidation by reducing serum MDA accumulation, with the optimal dosage of $\mathrm{Zn}$ from ZnPal being $80 \mathrm{mg} / \mathrm{kg}$ diet (analyzed Zn content in the diet: $165 \mathrm{mg} / \mathrm{kg}$ ), and $60 \mathrm{mg} / \mathrm{kg} \mathrm{Zn}$ as $\mathrm{ZnPal}$ (analyzed $\mathrm{Zn}$ content in the diet: $148 \mathrm{mg} / \mathrm{kg}$ ) was the optimum dosage for broilers to achieve maximum antioxidant enzyme activities.

Keywords: Zinc Bearing Palygorskite; Mineral Element; Superoxide Dismutase; Malondialdehyde; Broilers

\section{INTRODUCTION}

The reactive free radicals, like reactive oxygen species (ROS), are routinely produced during metabolism in animals. Generally, the amounts of these radicals maintain a balanced status and are not harmful for metabolism and health of animals in the presence of an effective antioxidant defense system [1]. However, when the over production of ROS exceeds the defence capacity of the host's antioxidant system, it will trigger lipid peroxidation that would induce oxidative damages to DNA and proteins, disintegrate the cellular membrane, disturb the balance between oxidants and antioxidants, and eventually induce the occurrence of oxidative stress, which is often regarded as one of the causes of several pathologies that affect poultry growth [1,2]. Antioxidant 
defense system is comprised of non-enzymatic and enzymatic antioxidant system. The enzymatic antioxidant system includes glutathione peroxidase, catalase, copper/zinc superoxide dismutase $(\mathrm{Cu} / \mathrm{Zn} \mathrm{SOD})$, and small molecular antioxidants as reduced glutathione, and this antioxidant system can efficiently protect the integrity of cellular membrane and maintain normal function of tissues through removing the excessive oxygen-derived free radicals and oxidizing products [2].

Zinc (Zn), as an essential trace element, acts both structurally and catalytically in various metalloenzymes, and therefore is indispensable for the growth, development, reproduction, and metabolic activities of both avian and mammalian species [3-5]. For broilers, $\mathrm{Zn}$ is usually supplemented to diets as $\mathrm{Zn}$ sulfate or $\mathrm{Zn}$ oxide to meet the requirement of birds since many natural feed ingredients are marginally deficient in $\mathrm{Zn} \mathrm{[6].} \mathrm{Zn}$ is the cofactor of $\mathrm{Cu} / \mathrm{Zn} \mathrm{SOD}$, a major antioxidant enzyme [7], and plays a key role in the antioxidant defense system $[8,9]$. Bun et al [5] reported that supplementation of organic $\mathrm{Zn}$ (from 20 to $60 \mathrm{mg} / \mathrm{kg}$ diet) to a corn-soybean basal diet (29.6 mg Zn/kg diet) ameliorated oxidative stress of broilers by increasing the activities of antioxidant enzymes including $\mathrm{Cu} / \mathrm{Zn} \mathrm{SOD}$, and inhibiting lipid peroxidation, irrespective of whether birds were healthy or challenged with Eimeria tenella. Similarly, Zhao et al [10] observed that $\mathrm{Zn}$ oxide nanoparticles inclusion improved the antioxidant capacity of broilers, as demonstrated by increased $\mathrm{Cu} / \mathrm{Zn}$ SOD activity and reduced malondialdehyde (MDA) accumulation in both serum and liver. Also, it has been demonstrated that $\mathrm{Zn}$ supplementation in the form of either inorganic or organic source improved the oxidative status in quail under heat stress $[11,12]$.

Palygorskite (Pal) is a naturally available magnesium aluminum silicate clay mineral with adsorption property, adhesive ability and cation exchange capacity [13]. In animal nutrition, $\mathrm{Pal}$, either as a feed ingredient or feed additive, has been widely incorporated in animal feed $[14,15]$. Due to the characteristics of Pal aforementioned, $\mathrm{Zn}$ bearing Pal ( $\mathrm{ZnPal}$ ) recently has been prepared using solid state ion exchange method [16]. In broilers, previous studies have shown that $\mathrm{ZnPal}$ could be used as a potential $\mathrm{Zn}$ source with a higher bioavailability than that of $\mathrm{Zn}$ sulfate [16]. In our previous study, the supplementation of $\mathrm{ZnPal}$ improved meat quality and its mineral composition, and enhanced muscle antioxidant capacity, whereas it did not affect the growth performance of broilers at 42 days of age [17]. In an in vivo study, Tang et al [18] found that $\mathrm{Zn}$ bearing clinoptilolite improved anti-oxidative status in the intestine of broilers as evidenced by increased $\mathrm{Cu} / \mathrm{Zn} \mathrm{SOD}$ activity and reduced accumulation of MDA, the end product of lipid peroxidation. Considering the similar physical and chemical characteristics among clays and the results of our previous study [17], we then hypothesized that the inclusion of $\mathrm{ZnPal}$ to diet would also improve the antioxidant capacity in the intestine and liver of broilers, and therefore the current study was conducted to investigate the effects of $\mathrm{ZnPal}$ supplementation on the growth performance, hepatic mineral content and antioxidant status in the liver and intestine of broilers at early age.

\section{MATERIALS AND METHODS}

\section{Preparation of $\mathrm{ZnPal}$}

The Pal was kindly offered by Jiangsu Sinitic Biotech Co., Ltd. (Xuyi, Jiangsu, China) and passed through a 200-mesh sieve (diameter, $0.074 \mathrm{~mm}$ ). The main chemical composition of Pal determined by a Minipal 4X-ray fluorescence spectrometer (PAN analytical Co., Eindhoven, Netherlands) are listed in the following: $\mathrm{SiO}_{2}, 59.11 \% ; \mathrm{MgO}, 12.75 \% ; \mathrm{Al}_{2} \mathrm{O}_{3}, 10.31 \%$; $\mathrm{CaO}, 7.42 \%$; $\mathrm{Fe}_{2} \mathrm{O}_{3}, 6.21 \% ; \mathrm{Na}_{2} \mathrm{O}, 1.27 \%$; and $\mathrm{K}_{2} \mathrm{O}, 1.19 \%$.

$\mathrm{ZnPal}$ was prepared according to method of solid state ion exchange as previously described by Yan et al [16]. Namely, Pal was firstly calcinated at around $300^{\circ} \mathrm{C}$ for $1 \mathrm{~h}$ in the muffle oven. After cooling down, Pal was mixed with $\mathrm{ZnCl}_{2}\left(\mathrm{ZnCl}_{2} \geq 98.0 \%\right.$; 4:1, wt/wt) purchased from Nanjing Chemical Reagent Co., Ltd. (Nanjing, Jiangsu, China) in a stainless steel blade grinder (HJ6A, Changzhou Guohua Electric Appliance Co., Ltd., Changzhou, Jiangsu, China). The mixture was subsequently calcinated at $300^{\circ} \mathrm{C}$ for $3 \mathrm{~h}$ in a muffle oven. After cooling down to room temperature, the mixture was washed repeatedly by deionized water until there was no white deposition generated in the washed solution when swigged with $0.1 \mathrm{~mol} / \mathrm{L} \mathrm{AgNO}_{3}$ solution. Finally, the washed mixture were collected and dried at around $105^{\circ} \mathrm{C}$ for $2 \mathrm{~h}$ in an air oven, and then passed through a 200-mesh sieve after cooling down. The amount of $\mathrm{Zn}$ adsorbed by Pal was 47.15 $\mathrm{mg} / \mathrm{g}$.

\section{Experimental design, diets and management} All procedures were approved by Nanjing Agricultural University Institutional Animal Care and Use Committee. Experimental design, diets and management in this study was the same to that of our previous study [17]. Briefly, a total of 2401 -day-old Arbor Acres broiler chicks (initial weight, $36.71 \pm 0.18 \mathrm{~g}$ ) obtained from a commercial hatchery were randomly allocated into 5 dietary treatments with 6 replicates (cages) of 8 chicks each (4 males and 4 females/cage). Birds in the 5 treatments were given a basal diet supplemented with 0 (Control group), 20, 40, 60, and $80 \mathrm{mg} \mathrm{Zn/kg}$ diet as $\mathrm{ZnPal}$ for 21 days, respectively. The formulation and calculated nutrient level of basal diet are shown in Table 1. All birds were placed in wired cages and housed in an environmentally controlled room with continuing light. Temperature was maintained at $32^{\circ} \mathrm{C}$ to $34^{\circ} \mathrm{C}$ for the first 3 days and then reduced by $2^{\circ} \mathrm{C}$ to $3^{\circ} \mathrm{C}$ per week until a final temperature of $26^{\circ} \mathrm{C}$ was achieved. Birds were allowed ad libitum access to mash feed and water.

\section{Growth performance}

At 21 days of age, birds were weighed by cage (replicate) after a 12-h fasting period to determine final body weight, and feed consumptionin each cage during the 21 days was recorded by 
Table 1. Composition and nutrient level of basal diet ( $/ \mathrm{kg}$, as fed basis unless otherwise stated)

\begin{tabular}{lc}
\hline Items & $\mathbf{1 - 2 1 ~ d}$ \\
\hline Ingredients & \\
Corn & 576.1 \\
Soybean meal & 310 \\
Corn gluten meal & 32.9 \\
Soybean oil & 31.1 \\
Limestone & 12 \\
Dicalcium phosphate & 20 \\
L-lysine & 3.4 \\
DL-methionine & 1.5 \\
Sodium chloride & 3 \\
Premix & 10 \\
Calculated nutrient levels ${ }^{2)}$ & \\
Apparent metabolizable energy (MJ/kg) & 12.56 \\
Crude protein & 211 \\
Calcium & 10.00 \\
Available phosphorus & 4.60 \\
Lysine & 12.00 \\
Methionine & 5.00 \\
Methionine+cystine & 8.50 \\
Analyzed composition & \\
Crude protein & 208 \\
Ash & 57.2 \\
\hline Prenix provided kilogam & \\
\hline
\end{tabular}

1) Premix provided per kilogram of diet: transretinyl acetate, $24 \mathrm{mg}$; cholecalciferol, $6 \mathrm{mg}$; all-rac- $\alpha$-tocopherol acetate, $20 \mathrm{mg}$; menadione, $1.3 \mathrm{mg}$; thiamin, $2.2 \mathrm{mg}$; riboflavin, $8 \mathrm{mg}$; nicotinamide, $40 \mathrm{mg}$; choline chloride, $400 \mathrm{mg}$; calcium pantothenate, $10 \mathrm{mg}$; pyridoxine $\cdot \mathrm{HCl}, 4 \mathrm{mg}$; biotin, $0.04 \mathrm{mg}$; folic acid, $1 \mathrm{mg}$; vitamin $\mathrm{B}_{12}$ (cobalamin), $0.013 \mathrm{mg}$; Fe (from ferrous sulfate), $80 \mathrm{mg}$; Cu (from copper sulphate), $8.0 \mathrm{mg} ; \mathrm{Mn}$ (from manganese sulphate), $110 \mathrm{mg}$; Zn (from zinc oxide), $60 \mathrm{mg}$; ( (from calcium iodate), 1.1 $\mathrm{mg}$; Se (from sodium selenite), $0.3 \mathrm{mg}$.

${ }^{2)}$ The nutrient levels were as fed basis.

${ }^{3)}$ Values based on analysis of triplicate samples of diet.

subtracting residual feed from the total feed provided. Average daily feed intake (ADFI) was measured by dividing average feed consumption (feed consumption divided by bird number) by the days (21 day). Average daily gain (ADG) was calculated by dividing average body weight gain (average final body weight subtracted average initial body weight) by the days. During the experiment, dead birds were recorded and weighed. Feed/gain ratio $(\mathrm{F}: \mathrm{G})$ was calculated by dividing average feed intake by average weight gain, including weight gain of any dead birds.

\section{Sample collection}

At 21 days of age, 6 birds per treatment ( 1 broiler per replicate) were selected and weighed. Blood samples (around $8 \mathrm{~mL}$ ) were taken from the wing vein before slaughter, and serum was separated by centrifugation at $3,000 \mathrm{~g}$ for $15 \mathrm{~min}$ at $4^{\circ} \mathrm{C}$, which was then stored at $-20^{\circ} \mathrm{C}$ until analysis. After that, birds were euthanized by cervical dislocation. After dissection, a portion of the right lobe of liver samples were excised, washed twice with phosphate buffer solution ( $\mathrm{pH}=7.4$ ), dried with filter paper, minced, snapped frozen in liquid nitrogen, and then stored at $-20^{\circ} \mathrm{C}$ for subsequent analysis. Meanwhile, jejunum (from the end of pancre- atic loop to the Meckel's diverticulum) and ileum (from Meckel's diverticulum to the ileocecal junction) were removed of the mesentery and placed on a chilled stainless steel tray immediately, which were then opened longitudinally, and the intestinal digesta were flushed with ice-cold phosphate buffered saline. After that, the jejunal and ileal mucosa were scrapped carefully using a sterile glass microscope slide, rapidly frozen in liquid nitrogen and then stored at $-80^{\circ} \mathrm{C}$ for further analysis.

\section{Hepatic mineral content determination}

The contents of $\mathrm{Zn}, \mathrm{Cu}$, manganese ( $\mathrm{Mn})$, iron (Fe), and magnesium $(\mathrm{Mg})$ in the liver and feed samples were determined according to the method described by Tang et al [19], which was further optimized by Yan et al [16]. Briefly, $0.50 \pm 0.02 \mathrm{~g}$ feed or $2.0 \pm 0.1 \mathrm{~g}$ fresh liver samples were weighed into a glass digestion tube, mixed with $10 \mathrm{~mL}$ of a mixture acid of nitric acid and perchloric acid (4:1, vol/vol) at room temperature for $12 \mathrm{~h}$, and then digested on a heating block (LabTech DigiBlock Digester, EHD36, Labtech Co., Ltd., Beijing, China) to acquire clear digested solution. The procedure of digestion was in the following: $90^{\circ} \mathrm{C}$ for $30 \mathrm{~min} ; 120^{\circ} \mathrm{C}$ for $30 \mathrm{~min} ; 160^{\circ} \mathrm{C}$ for $120 \mathrm{~min} ; 180^{\circ} \mathrm{C}$ for $180 \mathrm{~min}$. After that, digested solutions were diluted with ultra-pure water (high performance liquid chromatography-grade water) that was prepared using a Milli-Q system (Millipore, Molsheim, France) to a final volume of $25 \mathrm{~mL}$. The final solutions were analyzed for mineral content by an inductively coupled plasma mass spectrometry (Optimal 2100 DV, Perkin-Elmer-Sciex, Norwalk, NY, USA). The operating conditions were: power, $1,300 \mathrm{~W}$; plasma gas flow rate, $12 \mathrm{~L} / \mathrm{min}$; auxiliary gas flow rate, $0.2 \mathrm{~L} / \mathrm{min}$; nebuliser gas flow rate, $0.55 \mathrm{~L} / \mathrm{min}$; sample flow rate, $1.5 \mathrm{~mL} / \mathrm{min}$; sample uptake rate, $1.0 \mathrm{~mL} / \mathrm{min}$. Validation of the minerals analysis was conducted using a certified bovine liver powder (GBW (E) 080193; National Institute of Standards and Technology, Beijing, China) as a standard reference material. Analyzed mineral element content in the diets is presented in the Table 2.

\section{Measurement of serum antioxidant parameters}

Serum samples were analyzed for the activities of total superoxide dismutase (T-SOD, \# A001-1) and Cu/ZnSOD (\# A001-2), and MDA (\# A003-1) content using commercial kits (Nanjing Jiancheng Bioengineering Institute, Nanjing, China) according

Table 2. Analyzed trace minerals content in the diets during 1 to 21 days (mg/kg)

\begin{tabular}{lccccc}
\hline \multirow{2}{*}{ Items $^{1)}$} & \multicolumn{5}{c}{ Zn as ZnPal (mg/kg) } \\
\cline { 2 - 6 } & $\mathbf{0}$ (Basal diet) & $\mathbf{2 0}$ & $\mathbf{4 0}$ & $\mathbf{6 0}$ & $\mathbf{8 0}$ \\
\hline $\mathrm{Zn}$ & $81 \pm 2$ & $102 \pm 3$ & $120 \pm 2$ & $148 \pm 4$ & $165 \pm 3$ \\
$\mathrm{Fe}$ & $277 \pm 4$ & $280 \pm 7$ & $276 \pm 5$ & $283 \pm 7$ & $286 \pm 6$ \\
$\mathrm{Cu}$ & $22.8 \pm 0.3$ & $21.9 \pm 0.7$ & $22.5 \pm 0.5$ & $22.9 \pm 0.6$ & $23.5 \pm 0.4$ \\
$\mathrm{Mn}$ & $164 \pm 6$ & $163 \pm 3$ & $168 \pm 4$ & $170 \pm 5$ & $174 \pm 6$ \\
$\mathrm{Mg}$ & $1,825 \pm 13$ & $1,821 \pm 19$ & $1,848 \pm 14$ & $1,831 \pm 12$ & $1,817 \pm 14$ \\
\hline ZnPal, zinc bearing palygorskite. \\
${ }^{1)}$ Values based on analysis of triplicate samples of diets.
\end{tabular}


to the manufacturer's instructions. Briefly, the content of MDA was measured by barbiturate thiosulfate method, and the activity of SOD was determined by the hydroxylamine method. One unit of SOD was defined as the amount of SOD required to produce $50 \%$ inhibition of the rate of nitrite production at $37^{\circ} \mathrm{C}$.

\section{Measurement of hepatic and intestinal mucosal antioxidant parameters}

Around $0.30 \pm 0.01 \mathrm{~g}$ of liver or intestinal mucosa samples were homogenised (1:9, wt/vol) with ice-cold $154 \mathrm{mmol} /$ Lsterile sodium chloride solution using an Ultra-Turraxhomogeniser (Tekmar Co., Cincinatti, OH, USA) and then centrifuged at 4,000 $g$ for $15 \mathrm{~min}$ at $4^{\circ} \mathrm{C}$. The total protein concentrations were determined using a corresponding diagnostic kit (Nanjing Jian cheng Bioengineering Institute, China) according to the instructions of the manufacture. The determination methods of SOD activity and MDA concentration were the same as the measurements of serum samples. The concentration of MDA was expressed as nanomole per milligram protein of sample. All results were normalized to total protein concentration in each sample for innersample comparison (Value of enzyme activity [T-SOD and $\mathrm{Cu} / \mathrm{Zn}$ SOD] or MDA concentration in each sample was divided by corresponding total protein concentration).

\section{Statistical analysis}

Data were analyzed by one-way analysis of variance using SPSS (2008) statistical software (Ver. 16.0 for Windows, SPSS Inc., Chicago, IL, USA). The differences among treatments were examined by Tukey's test, which were considered to be significant at $\mathrm{p}<0.05$. Polynomial contrasts were used to determine the linear and quadratic effects of dietary ZnPal inclusion level. Means and standard errors were presented.

\section{RESULTS}

\section{Growth performance}

Treatments (Table 3 ) did not alter growth performance of broilers (ADFI, ADG, and F:G) during the 21-day study ( $\mathrm{p}>0.05$ ).

\section{Hepatic mineral content}

As indicated in Table 4, the contents of $\mathrm{Zn}$ and $\mathrm{Mg}$ in the liver were linearly $(\mathrm{p}<0.001)$ increased by $\mathrm{ZnPal}$ addition in the diet, and the maximum concentrations of $\mathrm{Zn}$ and $\mathrm{Mg}$ in the liver were observed when supplementing the basal diet with $80 \mathrm{mg} / \mathrm{kg} \mathrm{Zn}$ as $\mathrm{ZnPal}(\mathrm{p}<0.05)$. However, no significant differences were observed in the contents of hepatic $\mathrm{Fe}, \mathrm{Cu}$, or $\mathrm{Mn}$ among treatments $(\mathrm{p}>0.05)$.

\section{Serum antioxidant status}

$\mathrm{ZnPal}$ inclusion linearly $(\mathrm{p}=0.007)$ reduced the MDA concentration in serum (Table 5) of broilers, with the lowest MDA content being found in the diet supplemented with $80 \mathrm{mg} / \mathrm{kg} \mathrm{Zn}$ in the form of $\mathrm{ZnPal}(\mathrm{p}<0.05)$. Birds exhibited similar T-SOD and $\mathrm{Cu} / \mathrm{Zn}$ SOD activities in the serum among groups $(\mathrm{p}>0.05)$.

\section{Hepatic antioxidant status}

$\mathrm{ZnPal}$ supplementation (Table 6$)$ linearly $(\mathrm{p}=0.001)$ increased the activity of T-SOD in the liver of broilers, and its maximum response was observed in the diet supplemented with $60 \mathrm{mg} / \mathrm{kg} \mathrm{Zn}$ as $\mathrm{ZnPal}(\mathrm{p}<0.05)$. However, there were no differences in the activity of $\mathrm{Cu} / \mathrm{ZnSOD}$ or MDA concentration $(\mathrm{p}>0.05)$ among groups.

\section{Intestinal mucosal antioxidant status}

Supplementation of $\mathrm{ZnPal}$ (Table 7) linearly ( $\mathrm{p}=0.036$ ) and qua-

Table 3. Effects of zinc bearing palygorskite supplementation on the growth performance of broilers from 1 to 21 days of age

\begin{tabular}{|c|c|c|c|c|c|c|c|c|}
\hline \multirow{2}{*}{ Items } & \multicolumn{5}{|c|}{$\mathrm{Zn}$ as $\mathrm{ZnPal}(\mathrm{mg} / \mathrm{kg})$} & \multirow{2}{*}{ SEM } & \multicolumn{2}{|c|}{ p-value } \\
\hline & 0 (Control) & 20 & 40 & 60 & 80 & & Linear & Quadratic \\
\hline $\operatorname{ADG}(\mathrm{g} / \mathrm{d})$ & 29.88 & 29.21 & 29.26 & 29.89 & 30.43 & 0.24 & 0.414 & 0.100 \\
\hline $\operatorname{ADFI}(g / d)$ & 43.46 & 43.09 & 43.31 & 44.04 & 45.29 & 0.34 & 0.083 & 0.111 \\
\hline$F: G(g: g)$ & 1.45 & 1.48 & 1.48 & 1.48 & 1.49 & 0.01 & 0.109 & 0.679 \\
\hline
\end{tabular}

ZnPal, zinc bearing palygorskite; SEM, total standard error of means; ADG, average daily gain; ADFI, average daily feed intake; F:G, feed/gain ratio.

Table 4. Effects of zinc bearing palygorskite supplementation on the hepatic minerals content of broilers at 21 days of age (mg/kg fresh sample)

\begin{tabular}{|c|c|c|c|c|c|c|c|c|}
\hline \multirow{2}{*}{ Items } & \multicolumn{5}{|c|}{$\mathrm{Zn}$ as $\mathrm{ZnPal}(\mathrm{mg} / \mathrm{kg})$} & \multirow{2}{*}{ SEM } & \multicolumn{2}{|c|}{ p-value } \\
\hline & 0 (Control) & 20 & 40 & 60 & 80 & & Linear & Quadratic \\
\hline $\mathrm{Zn}$ & $20.41^{b}$ & $23.00^{\mathrm{ab}}$ & $24.65^{\mathrm{ab}}$ & $26.18^{a}$ & $28.01^{a}$ & 0.73 & $<0.001$ & 0.736 \\
\hline $\mathrm{Fe}$ & 64.70 & 70.42 & 74.40 & 73.57 & 74.35 & 1.66 & 0.065 & 0.469 \\
\hline $\mathrm{Mg}$ & $184.96^{b}$ & $197.21^{\mathrm{ab}}$ & $211.78^{\mathrm{a}}$ & $201.62^{\mathrm{ab}}$ & $218.76^{a}$ & 3.07 & $<0.001$ & 0.450 \\
\hline $\mathrm{Mn}$ & 2.95 & 3.24 & 2.96 & 3.32 & 3.30 & 0.08 & 0.154 & 0.940 \\
\hline $\mathrm{Cu}$ & 3.65 & 3.84 & 4.53 & 3.77 & 4.36 & 0.12 & 0.102 & 0.809 \\
\hline
\end{tabular}

ZnPal, zinc bearing palygorskite; SEM, total standard error of means.

${ }^{a, b}$ Means within a row with different superscripts are different at $p<0.05$. 
Table 5. Effects of zinc bearing palygorskite supplementation on the serum antioxidant capacity of broilers at 21 days of age

\begin{tabular}{|c|c|c|c|c|c|c|c|c|}
\hline \multirow{2}{*}{ Items } & \multicolumn{5}{|c|}{$\mathrm{Zn}$ as $\mathrm{ZnPal}(\mathrm{mg} / \mathrm{kg})$} & \multirow{2}{*}{ SEM } & \multicolumn{2}{|c|}{$p$-value } \\
\hline & 0 (Control) & 20 & 40 & 60 & 80 & & Linear & Quadratic \\
\hline T-SOD (U/mL) & 106.84 & 125.93 & 121.16 & 112.71 & 117.57 & 3.80 & 0.641 & 0.295 \\
\hline $\mathrm{Cu} / \mathrm{Zn} \mathrm{SOD}(\mathrm{U} / \mathrm{mL})$ & 69.35 & 76.46 & 74.83 & 73.51 & 76.16 & 1.51 & 0.463 & 0.546 \\
\hline MDA (nmol/mL) & $2.58^{\mathrm{a}}$ & $2.02^{\mathrm{ab}}$ & $2.32^{\mathrm{ab}}$ & $2.28^{\mathrm{ab}}$ & $1.80^{\mathrm{b}}$ & 0.09 & 0.007 & 0.952 \\
\hline
\end{tabular}

ZnPal, zinc bearing palygorskite; SEM, total standard error of means; T-SOD, total superoxide dismutase; Cu/Zn SOD, Cu/Zn superoxide dismutase; MDA, malondialdehyde.

$a, b$ Means within a row with different superscripts are different at $p<0.05$.

Table 6. Effects of zinc bearing palygorskite supplementation on the hepatic antioxidant capacity of broilers at 21 days of age

\begin{tabular}{|c|c|c|c|c|c|c|c|c|}
\hline \multirow{2}{*}{ Items } & \multicolumn{5}{|c|}{$\mathrm{Zn}$ as $\mathrm{ZnPal}(\mathrm{mg} / \mathrm{kg})$} & \multirow{2}{*}{ SEM } & \multicolumn{2}{|c|}{$p$-value } \\
\hline & 0 (Control) & 20 & 40 & 60 & 80 & & Linear & Quadratic \\
\hline T-SOD (U/mg protein) & $140.40^{b}$ & $148.25^{b}$ & $167.79^{\mathrm{ab}}$ & $191.35^{\mathrm{a}}$ & $173.79^{\mathrm{ab}}$ & 5.03 & 0.001 & 0.680 \\
\hline Cu/Zn SOD (U/mg protein) & 127.73 & 115.68 & 110.61 & 112.60 & 121.37 & 3.08 & 0.324 & 0.095 \\
\hline MDA (nmol/mg protein) & 0.67 & 0.64 & 0.64 & 0.57 & 0.75 & 0.31 & 0.747 & 0.211 \\
\hline
\end{tabular}

ZnPal, zinc bearing palygorskite; SEM, total standard error of means; T-SOD, total superoxide dismutase; Cu/Zn SOD, Cu/Zn superoxide dismutase; MDA, malondialdehyde.

a,b Means within a row with different superscripts are different at $p<0.05$.

dratically $(\mathrm{p}=0.005)$ increased the activity of T-SOD, and linearly $(\mathrm{p}=0.012)$ increased the activity of $\mathrm{Cu} / \mathrm{Zn} \mathrm{SOD}$ in jejunal mucosa. Broilers fed the diet supplemented with $60 \mathrm{mg} / \mathrm{kg} \mathrm{Zn}$ in the form of ZnPal exhibited the highest activities of jejunal T-SOD and $\mathrm{Cu} / \mathrm{Zn}$ SOD $(\mathrm{p}<0.05)$. Similarly, ZnPal supplementation quadratically $(\mathrm{p}=0.001)$ increased the activity of $\mathrm{Cu} / \mathrm{ZnSOD}$ in ileal mucosa, and the maximum activity of which was found in the diet supplemented with $20 \mathrm{mg} / \mathrm{kg} \mathrm{Zn} \mathrm{(}<<0.05)$. No significant differences were observed in the activity of ileal T-SOD or intestinal mucosal MDA content ( $\mathrm{p}>0.05)$.

\section{DISCUSSION}

In broilers, Bun et al [5] showed that the incorporation of an organic $\mathrm{Zn}$ source (methionine hydroxyl analog-Zn chelate) to a corn-soybean basal diet ( $29.6 \mathrm{mg} \mathrm{Zn/kg} \mathrm{diet)} \mathrm{from} 0$ to $60 \mathrm{mg} / \mathrm{kg}$ did not alter weight gain, feed intake and feed/gain ratio of healthy birds or birds challenged with Eimeria tenella. Similarly, in our present study, $\mathrm{ZnPal}$ supplementation did not affect the growth performance (ADG, ADFI, and F:G) in broilers from 1 to 21 days of age, and it was partially consistent with the results of Yan et al [16] who reported that broilers fed a basal diet $(35.2 \mathrm{mg} \mathrm{Zn/kg}$ diet) supplemented with $0,20,40,60$, or $80 \mathrm{mg} / \mathrm{kg} \mathrm{Zn}$ in the form of $\mathrm{ZnPal}$ exhibited similar growth performance (weight gain, feed intake, and feed conversion ratio) at 21 days of age. Actually, the similar growth performance of broilers among groups in this study lasted until the end of study (42 day) as reported in our previous study [17]. For broilers, Huang et al [20] have shown that the optimum concentration of $\mathrm{Zn}$ in chicken diet from hatch to 21 days of age is $84 \mathrm{mg} / \mathrm{kg}$. Additionally, Sunder et al [21] demonstrated that even $29 \mathrm{mg} / \mathrm{kg} \mathrm{Zn}$ present in corn-soybean meal basal diet was capable of supporting performance in broilers up to 4-wk of age. In the current study, the analyzed content of $\mathrm{Zn}$ in the basal diet was $81 \mathrm{mg} / \mathrm{kg}$ (Table 2), and thus the similar growth performance among treatments in our present study may be due to the $\mathrm{Zn}$ level in the basal diet, which was able to meet the growth requirements of chicks at early age. In contrast, Liu et al [22] reported that higher feed intake and weight gain were observed in broilers fed diet supplemented with 60,120 , or 180 $\mathrm{mg} / \mathrm{kg} \mathrm{Zn}$ in the forms of $\mathrm{ZnSO}_{4}, \mathrm{Zn}$ amino acid and $\mathrm{Zn}$ pro-

Table 7. Effects of zinc bearing palygorskite supplementation on the mucosal antioxidant capacity of broilers at 21 days of age

\begin{tabular}{|c|c|c|c|c|c|c|c|c|}
\hline \multirow{2}{*}{ Items } & \multicolumn{5}{|c|}{$\mathrm{Zn}$ as $\mathrm{ZnPal}(\mathrm{mg} / \mathrm{kg})$} & \multirow{2}{*}{ SEM } & \multicolumn{2}{|c|}{$\mathrm{p}$-value } \\
\hline & 0 (Control) & 20 & 40 & 60 & 80 & & Linear & Quadratic \\
\hline \multicolumn{9}{|l|}{ Jejunal mucosa } \\
\hline T-SOD (U/mg protein) & $63.45^{b}$ & $78.13^{\mathrm{a}}$ & $78.31^{\mathrm{a}}$ & $82.04^{\mathrm{a}}$ & $72.99^{\mathrm{ab}}$ & 1.79 & 0.036 & 0.005 \\
\hline Cu/Zn SOD (U/mg protein) & $32.36^{b}$ & $44.38^{\mathrm{ab}}$ & $37.50^{\mathrm{ab}}$ & $50.45^{\mathrm{a}}$ & $42.02^{\mathrm{ab}}$ & 1.98 & 0.012 & 0.133 \\
\hline MDA (nmol/mg protein) & 0.66 & 0.64 & 0.39 & 0.44 & 0.52 & 0.05 & 0.165 & 0.512 \\
\hline \multicolumn{9}{|l|}{ Ileal mucosa } \\
\hline T-SOD (U/mg protein) & 77.59 & 81.67 & 79.53 & 79.14 & 79.42 & 1.18 & 0.800 & 0.540 \\
\hline Cu/Zn SOD (U/mg protein) & $35.16^{b}$ & $54.65^{\mathrm{a}}$ & $43.13^{b}$ & $41.53^{b}$ & $40.20^{b}$ & 1.20 & 0.629 & 0.001 \\
\hline MDA (nmol/mg protein) & 0.76 & 0.57 & 0.72 & 0.74 & 0.69 & 0.05 & 0.867 & 0.541 \\
\hline
\end{tabular}

ZnPal, zinc bearing palygorskite; SEM, total standard error of means; T-SOD, total superoxide dismutase; Cu/ZnSOD, Cu/Zn superoxide dismutase; MDA, malondialdehyde.

${ }_{a, b}$ Means within a row with different superscripts are different at $p<0.05$. 
teinate when compared with those fed the basal diet $(35.6 \mathrm{mg} / \mathrm{kg})$ devoid of supplemental $\mathrm{Zn}$, and authors concluded that $90 \mathrm{mg} / \mathrm{kg}$ $\mathrm{Zn}$ was sufficient to reach an optimal growth performance in broilers since growth performance of broilers were similar among the $\mathrm{Zn}$-supplemented groups. Thus, this discrepancy among studies was most likely to result from level of $\mathrm{Zn}$ in the basal diet $(35.6 \mathrm{mg} / \mathrm{kg}$ ) of the study of Liu et al [22], unlike the present study $(81 \mathrm{mg} / \mathrm{kg})$, which could not meet birds' requirement for growth performance.

In poultry nutrition, Tang et al [19] have demonstrated that $\mathrm{Zn}$ concentration in the liver, pancreas and tibia in broilers at 14 days of age exhibited a linear response to an increasing concentration of $\mathrm{Zn}$ bearing zeolite clinoptilolite, an alternative $\mathrm{Zn}$ source to $\mathrm{Zn}$ sulfate. In this study, the supplementation of $\mathrm{ZnPal}$ also linearly increased $\mathrm{Zn}$ accumulation in the liver of broilers, indicating that $\mathrm{Zn}$ adsorbed by $\mathrm{Pal}$ was ready for use by broilers, which in turn enable $\mathrm{ZnPal}$ to be a potential $\mathrm{Zn}$ source. Similarly, Yan et al [16] have shown that dietary $\mathrm{ZnPal}$ or $\mathrm{Zn}$ sulfate supplementation increased $\mathrm{Zn}$ retention in the pancreas and tibia of broilers at both 21 and 42 days of age. The increased hepatic $\mathrm{Zn}$ concentration resulting from $\mathrm{ZnPal}$ supplementation observed in this study may be associated with its modulation on the mRNA abundances of metallothioneins and $\mathrm{Zn}$ transporters, the key mediators for $\mathrm{Zn}$ adsorption and transportation, as previously reported in broiler chickens [19] and laying hens [23] when supplemented with Zn bearing zeolite clinoptilolite. Dietary ZnPal supplementation linearly increased hepatic $\mathrm{Mg}$ in this study, and it was consistent with our previous results in the breast muscles of broilers [17]. The beneficial effects of $\mathrm{Zn}$ bearing zeolite or montmorillonite on the intestinal morphology of animals (one of the key factors for nutrient adsorption) have been observed previously $[18,24]$. In the current study, the analyzed Mg in the diets was similar among the five groups as indicated in the Table 2, and therefore the enhanced Mg accumulation in the liver may suggest a promoted $\mathrm{Mg}$ bioavailability in the $\mathrm{ZnPal}$. Considering the similar chemical and physical characteristics among clays, the enhanced $\mathrm{Mg}$ accumulation in the liver may be in related to the protective effect of $\mathrm{ZnPal}$ in the intestinal integrity.

The SOD, one of the most important antioxidant enzymes in the antioxidant defense system, ubiquitously exists innumerous cells of animals that could catalyze the disproportionation of superoxide to molecular oxygen and peroxide, and therefore is critical for protecting the cell against the toxic products of aerobic respiration $[7,25]$. As one of the isoforms of SOD, the enzyme $\mathrm{Cu} / \mathrm{Zn} \mathrm{SOD}$ has two identical subunits, and each subunit contains a metal cluster, the active site, constituted by a $\mathrm{Cu}$ and a $\mathrm{Zn}$ atom bridged by a histamine residue [26]. Cu/Zn SOD enzyme can coordinate the removal of oxygen free radicals and is believed to play a major role in the first line of antioxidant defense [7,26]. MDA is one of the end-products of lipid peroxidation by ROS, and the level of which is often regarded as an indicator of lipid peroxidation [27]. In this study, dietary Zn supplementation as
$\mathrm{ZnPal}$ inhibited the generation of MDA in the serum, and increased the activities of T-SOD and $\mathrm{Cu} / \mathrm{Zn}$ SOD in the tissues (liver and intestine), indicating that the inclusion of $\mathrm{ZnPal} \mathrm{im-}$ proved the antioxidant capacity of broilers at early age. Likewise, in an in vivo study, Bun et al [5] have shown that the inclusion of organic $\mathrm{Zn}$ improved oxidative status of broilers (irrespective of their health status) by increasing the activities of $\mathrm{Cu} / \mathrm{Zn} \mathrm{SOD}$ and glutathione peroxidase, and reducing MDA accumulation in the serum. Moreover, Zhao et al [10] also found that the incorporation of $\mathrm{Zn}$ oxide nanoparticles enhanced the antioxidant capacity of broilers. In this study, the improved oxidative status was in agreement with the simultaneously increased $\mathrm{Zn}$ retention in the liver, which in turn suggested that the enhanced antioxidant capacity may result from elevated $\mathrm{Zn}$ accumulation. The mode action of $\mathrm{Zn}$ in antioxidant defense system in vivo has been elucidated previously. First, $\mathrm{Zn}$ can protect cell membranes against iron-initiated lipid oxidation by occupying negatively charged sites with potential iron binding capacity [9]. Second, $\mathrm{Zn}$ is the cofactor of antioxidant enzymes including $\mathrm{Cu} / \mathrm{Zn} \mathrm{SOD}$ and metallothioneins $[7,28]$, which can serve as free radical scavengers. It is necessary to note that the most favorable antioxidant capacity in the liver and jejunum was observed when supplementing 60 $\mathrm{mg} / \mathrm{kg} \mathrm{Zn}$ instead of $80 \mathrm{mg} / \mathrm{kg}$. While for ileum, only $20 \mathrm{mg} / \mathrm{kg}$ $\mathrm{Zn}$ from $\mathrm{ZnPal}$ increased its $\mathrm{Cu} / \mathrm{Zn} \mathrm{SOD}$ activity, and the response of SOD activity to $\mathrm{Zn}$ supplementation in the serum was lacking, despite the fact that serum MDA concentration was linearly reduced with the increasing level of $\mathrm{ZnPal}$ in the diet. However, a clear explanation cannot be elucidated based on our knowledge of broilers at the present study, and these different responses of SOD activity to dietary $\mathrm{Zn}$ level may result from $\mathrm{Zn}$ deposition capacity of tissues, metabolic activity, amount and speed of ROS generation, and distribution of SOD enzymes.

In conclusion, feeding diets supplemented with $0,20,40,60$, and $80 \mathrm{mg} / \mathrm{kg} \mathrm{Zn}$ in the form of ZnPal did not affect the growth performance of broilers (weight gain, feed intake, and feed conversion ratio) in the 21-day study. Dietary $\mathrm{ZnPal}$ supplementation can promote the accumulations of hepatic trace mineral elements ( $\mathrm{Zn}$ and $\mathrm{Mg}$ ) and prevent lipid peroxidation by inhibiting serum MDA generation, with the optimal dosage of $\mathrm{Zn}$ from $\mathrm{ZnPal}$ being $80 \mathrm{mg} / \mathrm{kg}$ diet (analyzed $\mathrm{Zn}$ content in diet: $165 \mathrm{mg} / \mathrm{kg}$ ), and it appeared that $60 \mathrm{mg} / \mathrm{kg} \mathrm{Zn}$ as ZnPal (analyzed Zn content in diet: $148 \mathrm{mg} / \mathrm{kg}$ ) was the optimum dosage for broilers to achieve maximum antioxidant enzyme activities.

\section{CONFLICT OF INTEREST}

We certify that there is no conflict of interest with any financial organization regarding the material discussed in the manuscript.

\section{ACKNOWLEDGMENTS}

The technical assistance of our labmates are gratefully acknowl- 
edged.

\section{REFERENCES}

1. Rodriguez C, Mayo JC, Sainz RM, et al. Regulation of antioxidant enzymes: a significant role for melatonin. J Pineal Res 2004;36:1-9.

2. Birben E, Sahiner UM, Sackesen C, Erzurum S, Kalayci O. Oxidative stress and antioxidant defense. World Allergy Organ J 2012;5:9-19.

3. Park SY, Birkhold SG, Kubena LF, Nisbet DJ, Ricke SC. Review on the role of dietary zinc in poultry nutrition, immunity, and reproduction. Biol Trace Elem Res 2004;101:147-63.

4. Salim HM, Jo C, Lee BD. Zinc in broiler feeding and nutrition. Avian Biol Res 2008;1:5-18.

5. Bun SD, Guo YM, Guo FC, Ji FJ, Cao H. Influence of organic zinc supplementation on the antioxidant status and immune responses of broilers challenged with Eimeria tenella. Poult Sci 2011;90:1220-6.

6. Huang YL, Lu L, Li SF, Luo XG, Liu B. Relative bioavailabilities of organic zinc sources with different chelation strengths for broilers fed a conventional corn-soybean meal diet. J Anim Sci 2009;87:2038-46.

7. Perry JJP, Shin DS, Getzoff ED, Tainer JA. The structural biochemistry of the superoxide dismutases. Biochim Biophys Acta 2010;1804:24562.

8. Powell SR. The antioxidant properties of zinc. J Nutr 2000;130:1447S$54 \mathrm{~S}$.

9. Zago MP, Oteiza PI. The antioxidant properties of zinc: interactions with iron and antioxidants. Free Radic Biol Med 2001;31:266-74.

10. Zhao CY, Tan SX, Xiao XY, et al. Effects of dietary zinc oxide nanoparticles on growth performance and antioxidative status in broilers. Biol Trace Elem Res 2014;160:361-7.

11. Sahin K, Kucuk O. Zinc supplementation alleviates heat stress in laying Japanese quail. J Nutr 2003;133:2808-11.

12. Sahin K, Smith MO, Onderci M, et al. Supplementation of zinc from organic or inorganic source improves performance and antioxidant status of heat-distressed quail. Poult Sci 2005;84:882-7.

13. Bergaya F, Lagaly G. Handbook of clay science, 2th Edition. Developments in Clay Science vol. 5. Amsterdam, The Netherlands: Elsevier; 2013.

14. EU Commission. Regulation (EC) No. 1831/2003 of the European Parliament and of the Council of 23 September 2003 on additives for use in animal nutrition. Off J Eur Union L 2003;268:29-43.

15. Ministry of Agriculture of China. Beijing, China; 2013. Feed raw materials catalogue No. 2038

16. Yan R, Zhang L, Yang X, Wen C, Zhou YM. Bioavailability evaluation of zinc-bearing palygorskite as a zinc source for broiler chickens. Appl Clay Sci 2016;119:155-60.

17. Yang WL, Chen YP, Cheng YF, et al. An evaluation of zinc bearing palygorskite inclusion on the growth performance, mineral content, meat quality, and antioxidant status of broilers. Poult Sci 2016;95:87885.

18. Tang ZG, Wen C, Wang LC, Wang T, Zhou YM. Effects of zinc-bearing clinoptilolite on growth performance, cecal microflora and intestinal mucosal function of broiler chickens. Anim Feed Sci Technol 2014; 189:98-106.

19. Tang ZG, Chen GY, Li LF, et al. Effect of zinc-bearing zeolite clinoptilolite on growth performance, zinc accumulation, and gene expression of zinc transporters in broilers. J Anim Sci 2015;93:620-6.

20. Huang YL, Lu L, Luo XG, Liu B. An optimal dietary zinc level of broiler chicks fed a corn-soybean meal diet. Poult Sci 2007;86:2582-9.

21. Sunder GS, Panda AK, Gopinath NCS, et al. Effects of higher levels of zinc supplementation on performance, mineral availability, and immune competence in broiler chickens. J Appl Poult Res 2008;17: 79-86.

22. Liu ZH, Lu L, Li SF, et al. Effects of supplemental zinc source and level on growth performance, carcass traits, and meat quality of broilers. Poult Sci 2011;90:1782-90.

23. Li LF, Li P, Chen YP, et al. Zinc-bearing zeolite clinoptilolite improves tissue zinc accumulation in laying hens by enhancing zinc transporter gene mRNA abundance. Anim Sci J 2015;86:782-9.

24. Hu CH, Gu LY, Luan ZS, Song J, Zhu K. Effects of montmorillonitezinc oxide hybrid on performance, diarrhea, intestinal permeability and morphology of weanling pigs. Anim Feed Sci Technol 2012;177: 108-15.

25. Fridovich I. Superoxide anion radical $\left(\mathrm{O}_{2}^{-}\right)$, superoxide dismutases, and related matters. J Biol Chem 1997;272:18515-7.

26. MatÉs JÉM, Pérez-Gómez C, De Castro IN. Antioxidant enzymes and human diseases. Clin Biochem 1999;32:595-603.

27. Nielsen F, Mikkelsen BB, Nielsen JB, Andersen HR, Grandjean P. Plasma malondialdehyde as biomarker for oxidative stress: reference interval and effects of life-style factors. Clin Chem 1997;43:1209-14.

28. Tapiero H, Tew KD. Trace elements in human physiology and pathology: zinc and metallothioneins. Biomed Pharmacother 2003;57: 399-411. 